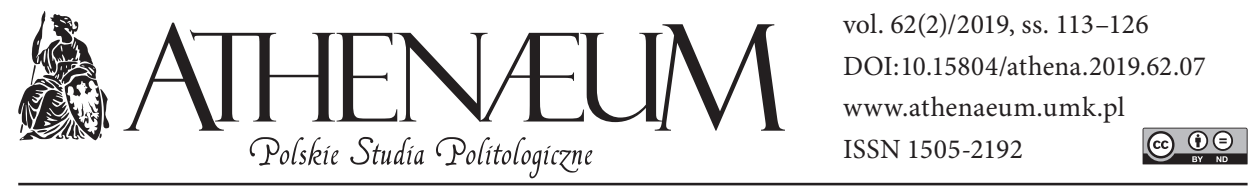

\title{
PRZESTRZEŃ JAKO DYNAMICZNY KONTEKST WSPÓŁCZESNEJ WŁADZY POLITYCZNEJ
}

\author{
SPACE AS A DYNAMIC CONTEXT OF CONTEMPORARY \\ POLITICAL POWER
}

\author{
Artur Laska* ${ }^{\circ}$
}

\begin{abstract}
ABSTRAKT
Autor niniejszego artykułu stawia sobie za cel analizę wpływu współczesnej transformacji przestrzeni oraz jej postrzegania na relacje władzy politycznej. Kontekst przestrzenny władzy sprowadza zarówno do jej korelatów materialnych, jak i niematerialnych, gdzie składają się na nią także konstrukty wytwarzane społecznie. W pierwszej kolejności przedmiotem analizy staje się więc wyróżnienie wzajemnych relacji między tak określonymi fenomenami. W dalszej części autor uwydatnia zjawisko dywersyfikacji źródeł władzy oraz analizuje jej dynamikę jako zasadniczą konsekwencję heterogenicznego charakteru przestrzeni. $\mathrm{Na}$ tej podstawie wyciąga wnioski teoretyczne, które mają stać się przydatne w badaniach empirycznych, a ponadto proponuje jeden $\mathrm{z}$ możliwych kierunków pożądanego organizowania władzy we współczesnych demokracjach.
\end{abstract}

Słowa kluczowe: władza polityczna; przestrzeń; miejsce; heterotopia; współrządzenie publiczne
The author of this article aims to analyze the impact of contemporary space transformation and its perception on the relations of political power. The spatial context of power reduces to its material and non-material correlates, where it is also composed of socially produced constructs. In the first place, the subject of the analysis is the distinction of mutual relations between such specific phenomena. In the following, the author emphasizes the phenomenon of diversifying the sources of power and analyzes its dynamics as a fundamental consequence of the heterogeneous character of space. On this basis, he draws theoretical conclusions that are to become useful in empirical research and proposes one of the possible directions for the desired organization of power in modern democracies.

Keywords: political power; space, place; heterotopias; public co-governance

* Uniwersytet Kazimierza Wielkiego w Bydgoszczy, Wydział Humanistyczny. 
Rozpatrywanie zdarzeń we wszechświecie z pominięciem czasu i przestrzeni nie ma sensu, ale bezsensowne jest również mówienie o czasie i przestrzeni poza wszechświatem

(Hawking, 1996, s. 44)

Władza polityczna jako zinstytucjonalizowana relacja społeczna, w sposób nieuchronny oraz immanentny ujawnia się w formach przestrzennych. Zgodzić się należy z Nigelem Thriftem, który wskazuje, że przestrzeń stanowi istotny element rządzenia już przynajmniej z tego względu, że aby „rządzić, trzeba unaocznić ludziom terytorium, które ma podlegać władzy. I nie jest to tylko kwestia samej fizyczności: przestrzeń władzy musi być uobecniona symbolicznie i zakreślona terytorialnie" (Thrift, 2002, s. 201-234; por. Allen, Massey, Cochrane, 1998, s. 137-138). Władza polityczna jest także czynnikiem sprawczym, warunkującym społeczne wytwarzanie przestrzeni i administrowanie miejscem. Praktyki przestrzenne są władczo regulowane w oparciu o zinstytucjonalizowane zasady. Nie oznacza to jednak, że taka organizacja miejsca musi być spójna. Wspomniane praktyki prowadzić mogą wręcz do wdrażania sprzecznych zasad porządkowania przestrzeni, co ostatecznie prowadzić może do dezorganizowania i rozpadania się miejsc. Tak jak w przypadku innych działań politycznych, trudno tutaj bowiem założyć ich pełen racjonalizm. Odniesienie do treści ideologicznych może implikować nie tylko wykorzystanie jej do budowania potencjału legitymizacyjnego, manipulowania przestrzenią, ale także oddania jej pod dyktat partykularnych interesów różnorodnych grup.

We wspomnianym zakresie regulacyjnym już od czasów starożytnych instrumentem władzy stało się planowanie przestrzenne. Zarówno grecka polis, jak i rzymskie obozy miasta były dziełami szczegółowo zaplanowanymi. Praktyka planowania rozwijana była także w średniowieczu, chociaż doktrynalną werbalizację kształtowanie przestrzeni zyskało ponownie w czasach renesansu. W XIX w. szczególne znaczenie przypadło opracowaniu regionalnych planów okręgów przemysłowych. Wizje takiego kreowania przestrzeni funkcjonowały na podbudowie ideologicznej, ale często opierały się także o doktryny urbanistyczne, stanowiące swoistą racjonalizację wdrażanych regulacji. Polegała ona zwykle na uzasadnieniu interwencji przestrzennych względami zdrowotnymi, estetycznymi, artystycznymi czy specyficznie definiowanym pojęciem dobra ogółu. Od zawsze jednak planowanie służyło celom bezpośrednio ideologicznym. Działo się tak na przykład wtedy, gdy dzieło urbanistyczne czy architektoniczne miało wzmacniać i podkreślać potęgę oraz prestiż władzy (Jałowiecki, 2010, s. 42-43). 
Za każdą formą przestrzenną kryją się więc konkretni aktorzy, którzy ją wytworzyli zgodnie ze swoimi interesami oraz ideologią, i których potrzeby ona zaspokaja. Szczególna rola przypada tutaj grupom dominującym w sferze ekonomicznej oraz symbolicznej. Przestrzeń stanowi wytwór ich żywej struktury i jako taka jest im niezbędna do samopodtrzymania pozycji i wpływów. Zachodzi jednak sprzężenie zwrotne, w którym przestrzeń oddziałuje także na grupy, warunkując ich zachowania. W efekcie wytwarzane przestrzennie instytucje stanowią także sposoby adaptacji do różnych środowisk (Sahlins, 1976).

Przez wieki to jednak państwo było dominującym aktorem społecznego wytwarzania przestrzeni. Z jednej strony pełniło względem niej funkcje strukturalne, oplatając jednolitą siecią instytucji biurokratycznych oraz kontroli. Prowadziło to między innymi do rozwoju stolic, czyli ośrodków władzy centralnej. W efekcie w ramach państwa przestrzeń stawała się ciągła. Z drugiej strony realizowało także funkcje strukturotwórcze, poprzez włączanie poszczególnych miejsc życia społecznego w jeden układ strukturalny. Uwzględniając grę partykularnych interesów społecznych, odwzorowywało w niej często hierarchie obecne wśród ludzi. Legitymizowało w ten sposób przestrzeń lepszą i gorszą, bogatą i biedną, bezpieczną i niebezpieczną, sacrum i profanum, centra i peryferie.

Dla współczesnych struktur politycznego władztwa szczególnie istotna wydaje się ostatnia z wymienionych opozycji. Centrum oznacza potęgę i siłę, nagromadzenie zasobów władzy, dóbr oraz informacji. To, co się w nim znajduje, jest widoczne i ważne, a bycie w nim daje poczucie sprawstwa, możliwości, wpływu oraz korzystania $\mathrm{z}$ różnego rodzaju urządzeń oraz udogodnień. Peryferie, im dalej od centrum, tym mają mniejszą wartość. Podział ten dotyczy także państw. Ten zanadto uproszczony układ dychotomiczny należy jednak skorygować teorią Immanuela Wallersteina, który zaproponował podział trójstopniowy na kraje rdzenia, półperyferii i peryferii (Wallerstein, 1979). Charakteryzuje go silna współzależność oparta na nieekwiwalentności wymiany surowców za towary przetworzone, gdzie peryferie i półperyferie pełnią funkcję służebną i uzupełniającą dla krajów rdzenia. W efekcie rozwój potencjalnych lub nie w pełni rozwiniętych metropolii w państwach półperyferyjnych jest indukowany przez państwa rdzenia, a zachodząca tam urbanizacja ma charakter naśladowczy. Zależność rozwoju i funkcjonowania metropolii od napływającego kapitału zagranicznego powoduje nierównomierne wytwarzanie przestrzeni i wzrost kontrastów między jego nowoczesnymi enklawami a pozostałymi obszarami konsumpcji. Kontrast między nową przestrzenią prywatną (gettoizacja) a starą publiczną widoczny jest w wielu tego typu ośrodkach. Uwarunkowania te tworzą specyficzne relacje 
między aktorami społecznego wytwarzania przestrzeni, a część grup uzyskuje bezwzględną przewagę (np. zagraniczni inwestorzy czy deweloperzy).

Wycofywanie się regulatora publicznego stanowi efekt ograniczenia zakresu i zasięgu władzy politycznej. W efekcie plany zagospodarowania przestrzeni są coraz mniej kompleksowe i rygorystycznie przestrzegane, co w dalszej kolejności skutkuje jej fragmentaryzacją i prywatyzacją. Ujawniający się tutaj deficyt władztwa politycznego wzmacnia oddziaływanie międzynarodowych korporacji, które wprowadzają tam nie tylko swoje standardy estetyczne, ale narzucają także określone sposoby zachowań i - co gorsze - ogałacają przestrzeń z infrastruktury publicznej (Jałowiecki, Szczepański, 2006, s. 424-425). Jej brak przekłada się na erozję tkanki społecznej.

Tego typu procesy ograniczają tradycyjnie rozumianą władzę polityczną, ale i dokonują swoistej dywersyfikacji jej źródeł. Inicjowana jest już nie tylko przez publiczne ośrodki decydowania, ale rozprasza się pośród wielorakich podmiotów, także prywatnych. Z tego względu ujmowanie władzy jako relacji doskonale asymetrycznej, zachodzącej w ograniczonej terytorialnie, ciągłej instytucjonalnie oraz homogenicznej kulturowo przestrzeni, wydaje się coraz mniej adekwatne. W zasadzie nigdy idea całkowitego domknięcia związku władzy, kultury i terytorium nie została w pełni zrealizowana. W ramach każdej formy związku politycznego ujawniały się różnorodne kultury, co istotnie ograniczało kontrolę nad obywatelami. Podobnie na odwrót, nawet przy istnieniu wspólnoty kulturowej, tworzono albo zróżnicowane jednostki polityczne, albo reżim polityczny rozrastał się daleko poza granice związku politycznego (np. w imperiach kolonialnych). Substancjalna wizja politycznych jednostek terytorialnych różnej skali, które posiadałyby jeden jasno zdefiniowany ośrodek władzy, współcześnie wydaje się tym bardziej nieuzasadniona.

Pojęcie przestrzeni samo w sobie jest bardziej abstrakcyjne niż miejsce. Stosuje się zarówno do rozciągłości, odległości między dwiema rzeczami bądź dwoma punktami, jak i do wielkości czasowej (Ague, 2012, s. 56, por. Yi-Fu Tuan, 1987, s. 13). Niemniej, już ogólna teoria względności odrzuciła pogląd, jakoby przestrzeń niezmiennie trwała. Będąc wytworem społecznym, stanowi jednocześnie pewną formę naoczności i wytwór umysłu. Jest to wielkość nie tylko zmienna i dynamiczna, ale przede wszystkim relacyjna, a w konsekwencji także względna (Lefebvre, 1991, s. 73). Przestrzeń nie do końca jest więc abstrakcją, lecz rzeczywistością społecznie wytworzoną, będąc jednym z czynników uczestniczących w kreacji społeczeństwa. Mówiąc inaczej, przestrzeń to nie praktyka miejsca, ale miejsc (Ague, 2012, s. 58). Relacje społeczne materializują się poprzez formalne 
lub nieformalne ich różnicowanie. Miejsca podlegają rozczłonkowaniu i dyferencjacji ze względu na kryteria funkcjonalne (użytek czyniony z miejsc) i strukturalne (ukształtowanie przestrzeni społecznej). W efekcie zostają podzielone na „wewnętrzne” i „zewnętrzne”, ,swoje” i „obce”, „prywatne” i „publiczne”, ,świeckie” i „święte”. Choć powstają granice, mury, zasieki, a przestrzeń ulega terytorializacji, to nadal rozciąga się lub kurczy, gęstnieje lub „ulega rozrzedzeniu” w zależności od tego, jak i gdzie przebiegają procesy integracji i dezintegracji społecznej.

W relacyjnej koncepcji przestrzeni społeczności lokalne, ale też innego typu terytoria (metropolie, regiony) traktowane są jako miejsca czy też obszary przecinania się otwartych, nieciągłych przestrzenności instytucjonalnych, nieustannie konstruowanych przez relacje i działania aktorów zbiorowych. Instytucje, w tym także te składające się na aparat władzy politycznej, nie istnieją po prostu w przestrzeni, tak jak ciała stałe w czasoprzestrzeni newtonowskiej, lecz mają tendencję do rozciągania się w różnej skali i na wiele sposobów. Z kolei sama przestrzeń nie stanowi jedynie ich kontekstu, ale odgrywa rolę czynnika aktywnego, nierzadko konfliktowego, modyfikującego ujawniające się zjawiska i procesy.

Wszystkie jednostki terytorialne, a także architektura, domy, ulice, budynki użyteczności publicznej i inne elementy krajobrazu stanowią rezultat procesu społecznego wytwarzania przestrzeni. Peter L. Berger i Thomas Luckmann słusznie zwracają uwagę, że ma on charakter dialektyczny, a o jego specyfice decydują trzy momenty: 1) tworzenie przez ludzi rzeczywistości społecznej, 2) uznanie przez nich obiektywności owej rzeczywistości oraz 3) zwrotne oddziaływanie zobiektywizowanego świata społecznego na postępowanie jednostek (Berger i Luckmann, s. 106). W ten sposób kształtowana jest więc przestrzeń społeczna, na którą składają się kulturowo określane relacje między ludźmi ze względu na uspołecznioną przestrzeń fizyczną (Jałowiecki, Szczepański, 2002, s. 303-304). Wpisując się właśnie w taki sposób myślenia, Florian Znaniecki wskazywał, że przestrzeń jest elementem ogólniejszego systemu wartości i w stosunku do niego uzyskuje dopiero treść i znaczenie. W ten sposób nabiera pewnej wartości samoistnej (Znaniecki, 1939, s. 91-94).

$\mathrm{Z}$ tego względu, posługiwanie się w analizie antynomią między wytworzoną w umyśle (subiektywną) przestrzenią a przestrzenią rzeczywistą, czyli między odniesieniem kategorii konceptualnych a tym, co fizyczne i równocześnie społeczne, stanowi przejaw ograniczenia poznawczego. Jeszcze bardziej nieaktualne staje się myślenie także innymi dychotomiami. Najtrwalsza z nich i często bezrefleksyjnie przyjmowana sprowadza się do wspomnianego podziału na endo- i egzogenne czynniki tworzenia miejsc. Równie myląca jest dzisiaj także 
dychotomia globalność - lokalność, która nie wyznacza już realnej opozycji. Wynika to z rosnącej heterogeniczności przestrzeni, którą tworzy sieć relacji wyznaczających miejsca wzajemnie do siebie nieredukowalne i niedające się na siebie nakładać. Ich status ontologiczny bywa zróżnicowany. Nie można ich scharakteryzować, można jedynie próbować je opisać, poszukując relacji między nimi. Wedle Michela Foucaulta część z nich pozostaje w związkach ze wszystkimi innymi na raz, ale w taki sposób, że zawieszają, neutralizują lub odwracają zastany układ relacji, który jest przez nie wskazywany czy odzwierciedlany (Foucault, 2005, s. 119-120).

Myślenie o przestrzeni wymaga więc unikania perspektywy osadzonej na dualistycznych opozycjach (przestrzeń/miejsce) na rzecz ich dialogizowania (Kita, 2003, s. 91). Nazbyt redukcjonistyczne staje się także koncentrowanie na jej walorach fizyczno-geograficznych. W dużym stopniu wynika to ze specyfiki ery elektronicznej, która zmienia konkretną przestrzeń publiczną w abstrakcyjną (to znaczy stworzoną elektronicznie, zob. Acconci, 1998, s. 81). Doświadczanie „rozciągłości przestrzeni” pociąga za sobą potrzebę zmiany całego paradygmatu jej analizy. Niezbędne staje się odstąpienie od układu wertykalnego, a więc myślenia synchronicznego, linearnego, podkreślającego dominację historii na rzecz horyzontalnego, odzwierciedlającego fakt jednoczesnego zaistnienia w przestrzeni rozmaitych zjawisk i procesów. W zgodzie z propozycją M. Foucaulta potrzebne jest więc wyciągnięcie wniosków z doświadczania rozciągłości przestrzeni oraz istnienia „miejsc jednoczesnych”.

$\mathrm{W}$ postulowane rozumienie przestrzeni wpisuje się perspektywa sieci, stworzonej z miejsc-punktów oraz relacji, ale w głównej mierze punktów heterogennych powstałych z nałożenia na siebie rozmaitych przestrzeni. Funkcjonujący w niej człowiek staje na styku różnych miejsc, przebywając w nich w tym samym czasie. W terminologii M. Foucaulta sieci takie występują pod nazwą heterotopii. Są to przestrzenie jakościowo nasycone, na które składają się punkty wzajemnie nieporównywalne, zarówno wyobrażeniowe, jak i realne, miejsca, a jednocześnie kontrmiejsca, w których wszystkie miejsca prawdziwe, które można znaleźć w kulturze, są jednocześnie reprezentowane, kontestowane i odwracane (Foucault, 2005, s. 121). Najważniejszą funkcją heterotopii jest to, że tworzą przestrzeń iluzji, która osłania tę realną, lub tworzy przestrzeń idealną. $\mathrm{W}$ relacji z rzeczywistością ujawnia nietrwałą, zmienną istotę rzeczy i jej fluktuacyjną naturę.

Wspomniane kontrmiejsca przyjmują także postać utopii i nie-miejsc. Te pierwsze wobec otaczającej rzeczywistości pozostają w relacji bezpośredniej 
lub w odwróconej analogii. Są miejscami zasadniczo nierealnymi, bez rzeczywistej przestrzeni. Ukazują społeczeństwo w udoskonalonej postaci, bądź też wywrócone „do góry nogami”. Nie-miejsca z kolei to przestrzenie hybrydyczne, niebędące miejscami antropologicznymi. Nie są możliwe do zdefiniowania jako relacyjne, czy też historyczne, mające potencjał kreowania tożsamości. Ich wzajemne podobieństwo i standardowość implikują deficyt poczucia przynależności i poczucie samotności przebywających tam ludzi, mogące prowadzić nawet do alienacji. Francuski antropolog Marc Augé twierdzi, że nie-miejsca to swoiste sfery tranzytowe, które jedynie udają tradycyjne przestrzenie. Tymczasem budują co najwyżej poczucie przelotności, bycia na chwilę i nie wymagają zaangażowania (Ague, 2012, s. 53, 71). W efekcie można wobec nich wysuwać sformułowania sprzecznościowe, opisujące doświadczenie bycia „w nich” i „poza nimi”; nieograniczonej mobilności i wynikającej z niej inercji.

Zastąpienie jednorodnej przestrzeni przez zmultiplikowane i heterogeniczne nie-miejsca prowadzi do relatywizacji sensu miejsca (Kita, 2003, s. 89-90). Powiązane z tym doświadczanie wspomnianego „usieciowienia” oznacza często zagubienie i osamotnienie jednostki. Nie każdy bowiem jest w stanie podołać wyzwaniom bycia rhizomatycznym w sensie, jakie nadali temu pojęciu Gilles Deleuze i Felix Guattari, czyli heterogenicznym kłączem wyposażonym w pamięć o krótkim trwaniu (Deleuze, Guattari, 1988). Metaforę kłącza cechuje odniesienie do charakterystyki przestrzeni nieciągłej - zarówno w zachowywaniu dowolności w łączeniu punktów-miejsc (zasada acentracji, wielości, ruchów deterytorializacyjnych i procesów reterytorializacyjnych), jak i w uprzywilejowaniu pamięci krótkiej nad długą (charakterystyczną dla rodziny, rasy, społeczeństwa czy cywilizacji).

Człowiek, będący kłączem w sieci, przeskakuje z miejsca na miejsce, z punktu wyjściowego do punktu wyznaczającego miejsce przeznaczenia, nie zważając na to, co znajduje się na linii łączącej owe miejsca. Zdany jest na swoistą tyranię mobilności. Wyposażony w nowoczesną technologię może jednocześnie znajdować się w radykalnie odmiennych i odległych przestrzeniach. W takiej rzeczywistości symultanicznego przebywania zarówno „tu”, jak i „tam”, ludzie zakorzenieni są jedynie dynamicznie, ale nigdzie nie czują się na dłużej zakotwiczeni. Przestrzeń, w jakiej się poruszają, traci więc na swojej konkretności i fizyczności. Jest to raczej przestrzeń przeżycia, tworząca się na styku rzeczywistości i medium (Kita, 2003, s. 83-85). Nawet chwilowe przebywanie w anonimowych nie-miejscach, które nie skutkuje ustanowieniem tożsamości, nie pozwala im doświadczać wspólnoty ludzkiego przeznaczenia. 
Brak przywiązania do miejsca powoduje powstanie tożsamości nomadycznej (tranzytowej), zmiennej i będącej w ciągłym poszukiwaniu, określanej przez nie-miejsca, które same nie wymagają tożsamości. Jest to jednak przestrzeń ciągłej rekompozycji i komunikacji, a co najważniejsze rozpadu jakiejkolwiek separacji terytorialnej. Jej momentalność sprowadza się do tego, że przyjmowana jest co najwyżej doraźnie, jedynie w chwili „teraźniejszej”, co wpisuje się w pewną ostateczną nieokreśloność i stanowi artykulację bytu niezdecydowanego. Kształtowanie takiej tożsamości publicznej, której zasadą jest możliwość identyfikacji z różnorodnymi alternatywnymi tożsamościami, wymaga ujawnienia się umysłu transwersalnego, który będzie sobie radzić $\mathrm{z}$ funkcjonowaniem w poprzek wielu racjonalności. Jest to jednak perspektywa nad wyraz optymistyczna. Częściej bowiem efektem staje się zniewolony umysł schizofreniczny, a podmiot poddany pośredniczącemu działaniu medium staje się schizoidalny (Chyła, 1998, s. 105-107). Bycie w wielości i pluralności obocznych rzeczywistości sprawia, że „stale się rozszczepia, bo zmysłowo doświadcza nieobecnego bycia” (Chyła, 1998, s. 112). Podmiot schizoidalny jest niezdolny do jakiejkolwiek formy przypisania cech stałych - w ramach określonych byciem w jednym ze światów, a tym samym do ukonstytuowania esencjonalnej i trwałej tożsamości.

Współcześnie pojawia się więc coraz więcej argumentów wskazujących, że koncentrowanie się na państwach, regionach, miastach czy wsiach, jako poziomach organizacji terytorialnej o wyraźnie zdefiniowanych granicach, nie wytrzymuje krytyki. Przykładowo, zgodzić się należy z reprezentantami krytycznego realizmu w geografii społecznej, którzy odrzucają ujmowanie regionu jako „poziomu pośredniego” pomiędzy państwem a „społecznościami lokalnymi”. Równie krytycznie odnoszą się do synonimicznego traktowania słów region i miejsce (Passi, 2002, s. 806). Adekwatne rozumienie tego, czym są regiony, wymaga według nich konceptualizowania ich jako przestrzeni otwartych, nieciągłych, relacyjnych i wewnętrznie zróżnicowanych (Hudson, 2006, s. 161-162). Zasadniczą kwestią pozostaje więc nie to, gdzie i jak przebiegają regionalne granice, lecz poprzez jakie procesy są owe terytoria, obszary czy miejsca (re)produkowane jako całości społeczno-kulturowe, polityczne czy ekonomiczne.

Nie tylko „substancjalna” wizja jednostek terytorialnych różnej skali, które byłyby zuniformizowane kulturowo i posiadały jasno zdefiniowany ośrodek, wydaje się już dzisiaj nieaktualna. Władza ujmowana jako asymetryczna relacja domknięta społecznie i terytorialnie napotyka na podobnie zdecydowaną krytykę. 
Koncepcję strukturalnej asymetrii władzy ściśle powiązanej z asymetrią terytorialną także zakwestionował wspomniany M. Foucault, wskazując na potencjał oporu wiedzy/władzy, tworzący się na peryferiach toczących się dyskursów. Zauważa on, że władza państwa nad obywatelami polega nie tyle na panowaniu wynikającym z umowy społecznej, ale na kontroli nad zachowaniami obywateli poprzez manipulację ich oczekiwaniami przy użyciu technik dyscyplinowania i różnych form wiedzy. Tam, gdzie dostęp do tej ostatniej ulega otwarciu, tam władza zaczyna krążyć i ulega rozproszeniu - także terytorialnemu. Zasadniczą rolę pełnią te metody i techniki, które pozwalają kontrolować i dyscyplinować zachowania „na odległość”. Władza jest skuteczna, dopóki umożliwia sterowanie uwewnętrznionymi dyspozycjami do określonych zachowań dzięki zrutynizowanym i zrytualizowanym praktykom, będącym efektem metod dyscyplinarnych. Zaproponowana przez filozofa koncepcja wydaje się przydatna w analizie władzy we współczesnych społeczeństwach. Zasadniczą kwestią w ramach tego ujęcia pozostaje nie to, kto władzę posiada, ale dotarcie do „matryc przekształceń, swoistych mechanizmów kodowania wiedzy i władzy, w tym procesów ich rozchodzenia się i krążenia w przestrzeni społecznej.

Z kolei Anthony Giddens ukazuje „konstruktywny” potencjał władzy, definiując ją jako transformatywną zdolność podmiotową, polegającą na przekształcaniu środków i zasobów w rezultaty (Giddens, 2001, s. 161). W znaczeniu relacyjnym realizowana jest w warunkach, w których możliwość osiągania celów zależy od podmiotowych działań innych. „W tym właśnie sensie ktoś może mieć władzę nad innymi; jest to władza jako dominacja” (Giddens, 2001, s. 162). Jest to jednak szczególny przypadek relacji władzy, zachodzący w sytuacji, w której przeprowadzenie czyjejś woli realizuje się wbrew oporowi innych. Tak jednak być nie musi, dlatego A. Giddens uważa, że ujmowanie władzy wyłącznie w kontekście konfliktu jest nadużyciem. Sprawowanie jej nie zawsze musi napotykać opór czy niechęć ze strony tych, którzy wspomnianej zdolności transformatywnej doświadczają.

Ideę domknięcia terytorialnego władzy podważa także Pierre Bourdieu. Choć traktuje ją jako zjawisko asymetryczne, to podkreśla, że jest ona aspektem każdej relacji społecznej i jako taka nie stanowi samodzielnego wymiaru interakcji. Wskazuje, że przestrzenny potencjał władzy może być co najwyżej wtórnie wykorzystany w grze sił rozgrywających się w każdym z instytucjonalnych pól jako jeden z jej kapitałów. To właśnie pola społeczne, a nie terytorialne, są jej podstawą (Bourdieu, Wacquant, 2001, s. 82). Tak więc przestrzeń geograficzna ma wobec nich charakter co najwyżej wtórny, a znaczenie oraz siła oddziaływania 
(wielkość) pola instytucjonalnego zależy od specyfiki budujących go relacji, w tym także władzy.

Zaproponowane ujęcia jednoznacznie demaskują złudność przekonania, jakoby władza $\mathrm{z}$ definicji związana była z przymusem lub dominacją osadzoną w ramach konkretnej przestrzeni terytorialnej. Problematyzują tradycyjne pojęcie władzy lokalnej, regionalnej, państwowej jako jednoznacznie określonego centrum politycznego. Co najważniejsze jednak, w kontekście ujawniającej się dzisiaj dynamiki przestrzennej wydają się po prostu bardziej adekwatne. Przykładowo, teoria A. Giddensa znaleźć może szerokie zastosowanie zarówno w koncepcjach władzy sieciowej, jak i w metaforze „władzy ku”, czyli swoistej zdolności mobilizowania i przekształcania rozmaitych zasobów materialnych i symbolicznych dla pewnej wizji dobra. Władza jako „zdolność transformatywna" stanowić może instrument integracji wokół wspólnych celów, przeciwdziałając w ten sposób rozbijającym lokalne społeczności skutkom procesów instytucjonalnych (globalnych, narodowych, indywidualnych), które przebiegają poza i ponad skalą lokalną. W efekcie ważna staje się próba odpowiedzi na pytanie: czy w sytuacji, gdy coraz większa część ludzkości przynajmniej częściowo żyje poza terytorium i powstaje swoiste napięcie między ideami terytorialności i uniwersalności, zlokalizowany związek polityczny winien wypracować nową formułę umiejscowionej ekspresji władzy?

Współcześnie nie tylko w badaniach władzy, ale także w próbach jej strukturalizacji konieczne staje się uwzględnianie różnych przestrzenności. Odrzucenie wspomnianych wcześniej dualizmów nie tylko nie pozwala postrzegać ram lokalnych, jako efektu procesów jedynie endogennych, ale wymaga rezygnacji z równie jednostronnej perspektywy sprowadzającej je do rezultatu „globalnej sieci i przepływów”, gdzie stają się niby „ofiarą" wielkoskalowych procesów globalizacji i deterytorializacji (Urry, 2009, s. 11). W badaniach tych ostatnich podkreśla się często, że miejsca stają się wypadkową „oddziaływań na odległość" i są bardziej wytworami globalnych mobilności kapitałów, intensywnych migracji, przepływów treści kulturowych, aniżeli uspołecznioną przestrzenią autochtonicznych grup ludzi. Fascynacja tą dynamiką nie powinna jednak przysłaniać faktu, że tworzenie i odtwarzanie miejsc w warunkach globalizacji nie ogranicza się do oddziaływań zachodzących w wielkich, globalnych skalach przestrzennych. Choć są one przez te procesy istotnie zapośredniczone, to równie ważne jest właściwe uwzględnianie determinacji zjawisk wypełniających jedynie lokalne ramy przestrzenne. Tylko w ten sposób wyciągnąć można konsekwencje ze słusznego założenia o heterogeniczności przestrzeni. 
Rację ma więc Saskia Sassen, wskazując, że badacze globalnych miast winni brać pod uwagę, że ich mieszkańcy funkcjonują jednocześnie w ponadnarodowych przestrzennościach, wyznaczonych relacjami powstającymi dzięki globalnym rynkom, ale także w znacjonalizowanych ramach przestrzennych państw narodowych (Sassen, 2001, s. 272). W efekcie miasta takie stają się specyficzną formą dystrybucji praktyk i treści kulturowych, które są zarówno wytworami lokalnymi, efektem oddziaływań państwa narodowego, ale i wykraczają poza jego granice, gdyż ich ramy przestrzenne mają często charakter globalny bądź transnarodowy. Nawet jeśli władztwo tradycyjnie rozumianego państwa traci na znaczeniu, to nie przestaje być jednym z elementów sieci relacji politycznych.

Argumentem uzasadniającym konieczność poszukiwania ekspresji władzy, która choć uwzględniałyby różne przestrzenności oraz ich nakładanie się, to byłaby jednak formą umiejscowioną, jest ujawniająca się tęsknota oraz zapotrzebowanie ludzi na praktyczne przywołanie idei miejsca. W szczególności dzieje się tak w sytuacji ofensywy wspomnianych nie-miejsc, w efekcie czego wszystko zaczyna się do siebie upodabniać i coraz trudniej odnaleźć przejawy autentyzmu otoczenia. $Z$ tego względu coraz częściej następuje przywracanie miejsc, mających silny potencjał generowania tożsamości, co przykładowo przyjmuje postać rewitalizacji zdegradowanych i dotychczas wykluczonych części miast.

Ponadto istnieje także zagrożenie, że ignorowanie, a wręcz całkowite odrzucenie lokalizacji władzy politycznej oraz strukturalizacji porządku miejsc w oparciu o nią, wzmocni niedemokratyczne nacjonalizmy. Historia udowodniła, że to budowane w oparciu o taką ideologię reżimy zdobywają poparcie między innymi przez obietnice ochrony obywateli przed poczuciem skurczenia się przestrzeni, co w praktyce odbywa się później kosztem ograniczenia wolności poruszania się i obiegu informacji. Taki renesans idei suwerennej i niepodzielnej władzy może więc stać się choć złudną, to nad wyraz ponętną odpowiedzią na poczucie przestrzennego zagubienia człowieka.

Sterowność związków politycznych wymaga, aby władzę rozproszoną w obrębie kodów różnych przestrzeni próbować koncentrować przez uczynienie określonego miejsca na nowo podmiotem działań politycznych. Będzie to możliwe jedynie poprzez dynamizowanie inicjatyw na rzecz danego miejsca, dzięki którym rozproszeni w rozmaitych dyskursach władzy aktorzy zjednoczą się wokół celów uwzględniających interes tego miejsca. Chodziłoby więc o efektywne wykorzystanie władzy jako zasobu, który może zostać użyty przez aktorów rozmieszczonych w różnych wymiarach przestrzeni społecznej. Jak twierdzi Ray Hudson, skuteczność owej koncentracji zależeć będzie od zdolności do zarzą- 
dzania oraz manipulowania przenikającymi ją dyskursami, procesami i mechanizmami kodowania społecznej wiedzy. Nawiązując do pojęcia governmentality, zauważa on, że łącząc pojęcia govern and mentality (rządzić/rządzenie oraz mentalność/umysłowość), postawione zostaje raczej pytanie o sposoby rządzenia i struktury władzy, a nie o to „kto” i „dlaczego” rządzi. W ten sposób zarządzanie można by określić jako „mniej lub bardziej skalkulowane i racjonalne działanie podejmowane przez rozmaite podmioty (władze różnych szczebli czy ich agendy) wykorzystujące różne techniki i formy wiedzy, aby wpływać na ludzkie zachowania poprzez manipulowanie potrzebami, aspiracjami, przekonaniami czy pragnieniami z zamiarem osiągania zarówno konkretnych, jak i zmiennych celów w warunkach zasadniczej nieprzewidywalności efektów, konsekwencji i rezultatów" (Hudson, 2006, s. 162-163).

W tego typu perspektywę wpisuje się idea współrządzenia publicznego ( $p u b l i c$ governance) jako zbiorowego procesu uzgadniania i realizacji wspólnych celów. Pojęcie to wprowadził do studiów nad władzą lokalną Peter John, co stanowiło próbę opisania zmian zachodzących w zarządzaniu europejskimi miastami od lat 70. XX w. Ich efektem była ewolucja hierarchicznych i zbiurokratyzowanych systemów władzy lokalnej w nowe, elastyczne i uspołecznione formy rządzenia (John, 2001, s. 9). Koncepcja ta osadza proces decyzyjny nie tyle w formalnej strukturze administracyjnej, lecz dynamicznej sieci relacji między kluczowymi oraz niekoniecznie sformalizowanymi podmiotami z różnych segmentów życia publicznego i na różnych szczeblach struktury terytorialnej. Ujawniająca się tutaj władza polega na mobilizacji zasobów i może być traktowana zgodnie z ujęciem giddensowskim jako „zdolność transformatywna”. Tony Bovaird wskazuje, że na takie współrządzenie składają się „sposoby, poprzez które interesariusze wchodzą ze sobą w interakcje, aby wpływać na efekty polityk publicznych" (Bovaird, 2005, s. 220). W efekcie podmiotem władzy staje się praktycznie cała społeczność lokalna, a sprawowanie jej na określonym obszarze (gminy, miasta, regionu czy państwa) polega na wdrażaniu strategii, projektów, programów, opartych na zebraniu danych $\mathrm{z}$ wielu źródeł i uwzględniających procesy zachodzące w różnych skalach. Stwarza to szansę na sterowanie rozwojem w obrębie określonej lokalizacji, uwzględniające nie tylko jej specyficzne zasoby, ale wielorakie oddziaływania $\mathrm{z}$ otoczeniem oraz innymi przestrzeniami, które mają na nią wpływ. W praktyce nie chodzi więc o to, aby to, co lokalne chronić przed tym, co globalne i transnarodowe, ale wręcz przeciwnie - wykorzystać pojawiające się tutaj szanse. Uspołecznienie procesu decydowania z kolei może integrować zbiorowość wokół konkretnego miejsca, a tym samym budować potencjał 
legitymizacji oraz konsolidować energię społeczną. Bez nich trudno wyobrazić sobie sterowność jakichkolwiek demokratycznych związków politycznych, a szczególnie tych, dla których to sieć okazuje się właściwym pryzmatem dla uchwycenia ich dynamiki.

Wskazane rozwiązanie wydaje się konstruktywną propozycją uwzględniającą zarówno scharakteryzowane procesy przestrzenne, jak i fundamentalne, gatunkowe uwarunkowania życia ludzi. Rozważanie politycznej kondycji człowieka nie może ignorować tego, w jaki sposób on sam wyraża się poprzez relacje przestrzenne i jak je buduje. Doświadczanie przez niego świata warunkowane jest bowiem przez jej dynamikę i heterogeniczność. W węźle różnorodnych przepływów żyje on w coraz to odmiennych kontekstach, co nierzadko wprowadza go w stan zagubienia i poczucia zagrożenia (Jałowiecki, 2010, s. 277-278). Paradoksalnie bowiem nie powoduje to wcale, że staje się niezależną i a-terytorialną monadą, ale wręcz przeciwne, lokalizacja, umiejscowienie i nadawanie sensu przestrzeni nadal pozostają jego podstawowymi potrzebami. Badacz polityki winien więc pamiętać, że choć zmienia się fizyczna i społeczna rzeczywistość, w tym także dynamicznie ewoluuje kultura człowieka, to jego fundamentalne oczekiwania pozostają niezmienne (zob. szerzej: Laska, 2017). Czym innym jest więc zauważać ową dynamikę relacji przestrzennych i uznać ich nieuchronność, a czym innym założyć, że w sposób całkowity zmieniają one człowieka. Bez względu na ich konsekwencje, których w badaniu i praktykowaniu polityki nie należy ignorować, konieczne jest równocześnie skoncentrowanie się na tradycyjnych funkcjach władzy politycznej. Choć zmieniają się okoliczności, a świat przybiera dziś postać wcześniej niespotykaną, to akurat w tej kwestii wiele się nie zmienia. Strukturyzacja przestrzeni, jak i budowanie tożsamości za pośrednictwem umiejscowionego władztwa nadal pozostaje ważnym wyzwaniem dla polityków. Byłoby dobrze, gdyby badacze polityki mogli im w tym względzie coś podpowiedzieć.

\section{BibLIOGRAFIA:}

Acconci, V. (1998). Przestrzeń publiczna w prywatnym czasie. W: J.S. Wojciechowski, A. Zeidler-Janiszewska (red.). Formy estetyzacji przestrzeni publicznej. Warszawa: Instytut Kultury.

Ague, M. (2012). Nie-miejsca. Wprowadzenie do antropologii hipernowoczesności. Warszawa: Wydawnictwo Naukowe PWN.

Allen, J., Massey, D., Cochrane A. (1998). Rethinking the Region. London: Psychology Press. 
Berger, P.L., Luckmann, T. (1983). Społeczne tworzenie rzeczywistości. Warszawa: PIW.

Bourdieu, P., Wacquant, L.J.D. (2001). Zaproszenie do socjologii refleksyjnej. Warszawa: Oficyna Naukowa.

Bovaird, T. (2005). Public Governance: Balancing Stakeholder Power in a Network Society, International Review of Administrative Sciences, 71(2), 217-228.

Chyła, W. (1998). Szkice o kulturze audiowizualnej: w stulecie ekranu w kulturze. Poznań: Wyd. Fundacji Humaniora.

Deleuze, G., Guattari, F. (1988). Kłącze, Colloquia Communia, 1/3, 221-238.

Foucault, M. (2005). Inne przestrzenie. Teksty Drugie, 6, 117-125.

Giddens, A. (2001). Nowe zasady metody socjologicznej. Pozytywna krytyka socjologii interpretatywnych. Kraków: Zakład Wydawniczy „Nomos”.

Hawking, S. (1996). Krótka historia czasu - od Wielkiego Wybuchu do czarnych dziur. Poznań: Zysk i S-ka.

Hudson, R. (2006). Regional Revolution and Regional Economic Success: Myths and Illusions About Power. Geografiska Annaler, 88B(2), 159-171.

Jałowiecki, B. (2010). Społeczne wytwarzanie przestrzeni. Warszawa: Wydawnictwo Naukowe Scholar.

Jałowiecki, B., Szczepański, M.S. (2006). Miasto i przestrzeń w perspektywie socjologicznej. Warszawa: Wydawnictwo Naukowe Scholar.

John, P. (2001). Local Governance in Western Europe. London: SAGE Publications.

Kita, B. (2003). Między przestrzeniami. O kulturze nowych mediów. Kraków: Rabid.

Laska, A. (2017). Teoria polityki. Próba ujęcia integralnego. Bydgoszcz: Wydawnictwo Uniwersytetu Kazimierza Wielkiego.

Lefebvre, H. (1991). The Production of Space. Oxford: Basil Blackwell.

Passi, A. (2002). Place and Region: Regional Worlds and Words. Progress in Human Geography, 28(6), 802-811.

Sahlins, M. (1976). Culture and Practical Reason. Chicago: University of Chicago Press. Sassen, S. (2001). Spatialities and Temporalities of the Global: Elements for Theorization, W: A. Appadurai (red.). Globalization. Durham-London: Duke University Press Books.

Thrift, N. (2002). Performing Cultures in the New Economy, W: P. du Gay, M. Pryke (red.). Cultural Economy: Cultural Analysis and Commercial Life. London: SAGE Publications Ltd.

Tuan, Yi-Fu (1987). Przestrzeń i miejsce. Warszawa: PIW.

Urry, J. (2009). Socjologia mobilności. Warszawa: Wydawnictwo Naukowe PWN.

Wallerstein, I. (1979). The Capitalist World Economy. New York: Cambridge University Press.

Znaniecki, F. (1939). Socjologiczne podstawy ekologii ludzkiej. Ruch Prawniczy, Ekonomiczny i Socjologiczny, 1, 89-119. 